\title{
Optimization of Growth Conditions for Purification and Production of L-Asparaginase by Spirulina maxima
}

\author{
Hanaa H. Abd El Baky ${ }^{1}$ and Gamal S. El Baroty ${ }^{2}$ \\ ${ }^{1}$ Plant Biochemistry Department, National Research Centre, P.O. Box 12026, Dokki, Cairo, Egypt \\ ${ }^{2}$ Biochemistry Department, Faculty of Agriculture, Cairo University, Cairo, Egypt \\ Correspondence should be addressed to Hanaa H. Abd El Baky; abdelbakyh@hotmail.com
}

Received 27 October 2015; Revised 3 April 2016; Accepted 30 May 2016

Academic Editor: Dolores García Giménez

Copyright @ 2016 H. H. Abd El Baky and G. S. El Baroty. This is an open access article distributed under the Creative Commons Attribution License, which permits unrestricted use, distribution, and reproduction in any medium, provided the original work is properly cited.

\begin{abstract}
L-asparaginase (L-AsnA) is widely distributed among microorganisms and has important applications in medicine and in food technology sectors. Therefore, the ability of the production, purification, and characterization of AsnA from Spirulina maxima (SM) were tested. SM cultures grown in Zarrouk medium containing different $\mathrm{N}_{2}$ (in $\mathrm{NaNO}_{3}$ form) concentrations $(1.25,2.50$, and 5.0 g/L) for 18 days contained a significant various quantity of dry biomass yields and AsnA enzyme levels. MS L-AsnA activity was found to be directly proportional to the $\mathrm{N}_{2}$ concentration. The cultures of $\mathrm{SM}$ at large scales $\left(300 \mathrm{~L}\right.$ medium, $5 \mathrm{~g} / \mathrm{L} \mathrm{N}_{2}$ ) showed a high AsnA enzyme activity $(898 \mathrm{IU})$, total protein $(405 \mathrm{mg} / \mathrm{g})$, specific enzyme activity $(2.21 \mathrm{IU} / \mathrm{mg}$ protein), and enzyme yield (51.28 IU/L) compared with those in low $\mathrm{N}_{2}$ cultures. The partial purification of crude MS AsnA enzyme achieved by $80 \%$ ammonium sulfate AS precipitated and CM-Sephadex C-200 gel filtration led to increases in the purification of enzyme with 5.28 and 10.91 times as great as that in SM crude enzymes. Optimum pH and temperature of purified AsnA for the hydrolyzate were 8.5 and $37 \pm 0.2^{\circ} \mathrm{C}$, respectively. To the best of our knowledge, this is the first report on $\mathrm{L}$-asparaginase production in $\mathrm{S}$. maxima.
\end{abstract}

\section{Introduction}

Enzymes are proteins that catalyze biochemical reactions. They are more important than vitamins and minerals for general health [1]. Hydrolases constitute a class of enzymes widely distributed in nature from bacteria to higher eukaryotes. L-asparaginase (L-asparagine amidohydrolase EC, 3.5.1.1) is an enzyme of high intensive chemotherapeutic application due to its use in wide variety of cancer therapy mainly in acute lymphoblastic leukemia [2]. It is used for treatment of various diseases such as childhood acute lymphoblastic leukemia, myelomonocytic leukemia, reticulum sarcoma, melanoma sarcoma, non-Hodgkin's lymphoma, pancreatic carcinoma, and bovine lymphoma sarcoma $[3,4]$. The enzyme deprives these types of cancer of L-asparagine because it catalyzes the deamination of L-asparagine, an essential amino acid for lymphoblast growth, to L-aspartic acid and ammonia thus shrinks these tumors [5]. Since the tumor cells require the high quantity of asparagine from the diet and from other cells for their rapid proliferation and depend on an external supply of L-asparagine for their growth, therefore, by continuous administering of Lasparaginase, the tumor cells are made to stave off that particular amino acid, which leads to the death of lymphoblasts by apoptosis [6]. These AsnA enzymes are produced by a large number of microorganisms that include bacteria (Streptomyces gulbargensis, Enterobacter cloacae, and Serratia marcescens), fungi, and yeast. All the forms of the enzyme have similar functionality and received important attention [7-11].

Recently, L-asparaginase is used in food technology as a potent mitigating agent for reducing the acrylamide (AA, $\mathrm{CH}_{2}=\mathrm{CH}-\mathrm{CO}-\mathrm{NH}_{2}$ ), a potential carcinogen, which is formed from the reaction of L-asparagine (L-AsnA) and reducing sugars contained in foods during heating processes [12]. However, a wide range of foods prepared by heating treatments above $160^{\circ} \mathrm{C}$ like coffee, bread, fried or roasted potato products, toasted bread, and sweet biscuit contained high amounts of AA (30-5,600 ng/g) [13]. Mohan Kumar et al. [14] have reported that AA had an adverse effect on human health 
and is proven to be neurotoxic, genotoxic, carcinogenic, and toxic to the reproductive system. Consequently, it is important to the application of AsnA in processed foods to suppress the formation of AA content to minimal levels, which could correspond to a negligible cancer risk in final food products [15].

More recently, production of L-asparaginase from bluegreen microalgae is receiving more attention due to its high nutrient contents, low cost of production, and cost-effectiveness, no seasonal variation, high efficient producers, being easily cultured and harvested at large scales, and cheaper and easier extraction, and higher yields and purification of protein and enzymes by simple methods are available [16]. However, few specific reports regarding production of AsnA by blue-green algae are recorded [16]. Thus, there is a need to identify algae species which produce high levels of asparaginase under low cost and simple culture conditions. Considering the importance of asparaginase, this study was carried out to produce optimized and characterized Lasparaginase from SM and determine the purification process and characterization of its properties.

\section{Material and Methods}

2.1. Algal Strains. Blue-green alga, Spirulina maxima, was cultivated in Plant Biochemistry Department, Algae Unit, National Research Centre, Cairo, Egypt.

2.2. Reagents. All reagents and chemicals used in this experiment were of analytical grade and purchased from SigmaAldrich Chemicals.

\subsection{Cultivation of Algae}

2.3.1. Preparation of Spirulina maxima Inoculums. S. maxima was cultivated (during spring season 2014, in National Research Centre, Egypt). It was grown in the modified Zarrouk medium [17] containing the following nutrients $\left(\mathrm{gL}^{-1}\right): \mathrm{Na}_{2} \mathrm{CO}_{3}, 4.03 ; \mathrm{NaHCO}_{3}, 13.61 ; \mathrm{NaCl}, 1.00 ; \mathrm{K}_{2} \mathrm{SO}_{4}$, 1.00; $\mathrm{NaNO}_{3}, 2.50 ; \mathrm{K}_{2} \mathrm{HPO}_{4}, 0.50 ; \mathrm{MgSO}_{4}, 0.20$; and $\mathrm{CaCl}_{2} \cdot 2 \mathrm{H}_{2} \mathrm{O}, 0.04$. All nutrients were dissolved in redistilled water containing (per liter) $6 \mathrm{~mL}$ of metal solution $(750 \mathrm{mg}$ $\mathrm{Na}_{2}$ EDTA, $97 \mathrm{mg} \mathrm{FeCl} \cdot 6 \mathrm{H}_{2} \mathrm{O}$, $41 \mathrm{mg} \mathrm{MnCl} \cdot 4 \mathrm{H}_{2} \mathrm{O}$, $5.0 \mathrm{mg}$ $\mathrm{ZnCl}_{2}, 2 \mathrm{mg} \mathrm{CoCl} \cdot 6 \mathrm{H}_{2} \mathrm{O}$, and $4.0 \mathrm{mg} \mathrm{Na}_{2} \mathrm{MoO}_{4} \cdot 2 \mathrm{H}_{2} \mathrm{O}$ ) and $1 \mathrm{~mL}$ of trace-nutrient solution $\left(50.0 \mathrm{mg} \mathrm{Na}{ }_{2}\right.$ EDTA, $618 \mathrm{mg} \mathrm{H}_{3} \mathrm{BO}_{3} \cdot 6 \mathrm{H}_{2} \mathrm{O} 324.7 \mathrm{H}, 19.6 \mathrm{mg} \mathrm{CuSO} \cdot 5 \mathrm{H}_{2} \mathrm{O}, 44.0 \mathrm{mg}$ $\mathrm{ZnSO}_{4} \cdot 7 \mathrm{H}_{2} \mathrm{O}, 0.20 \mathrm{mg} \mathrm{CoCl} \cdot 6 \mathrm{H}_{2} \mathrm{O}, 12.6 \mathrm{mg} \mathrm{MnCl}_{2} \cdot 4 \mathrm{H}_{2} \mathrm{O}$, and $\left.12.6 \mathrm{mg} \mathrm{Na}_{2} \mathrm{MoO}_{4} \cdot 2 \mathrm{H}_{2} \mathrm{O}\right)$.

2.4. Cultures Treatments. Nitrogen was supplied as $\mathrm{NaNO}_{3}$ with the concentrations of $1.25,2.5 \mathrm{~g} / \mathrm{L}$, and $5.0 \mathrm{~g} / \mathrm{L} \mathrm{NaNO}_{3}$ into a different flask containing 1.7-liter Zarrouk medium in a $2 \mathrm{~L}$ flask. Aeration was accomplished utilizing air pumps to achieve an air flow rate of $20 \mathrm{~L} / \mathrm{h}$. The cultures were gassed with $0.03 \%$ volume $\mathrm{CO}_{2}$ in the air and temperature was maintained at $25^{\circ} \mathrm{C} \pm 3^{\circ} \mathrm{C}$. The $\mathrm{pH}$ of all media was adjusted to 9.5 and monitored at $24 \mathrm{~h}$ intervals. The cultures were illuminated with perpetual $10 \mathrm{cool}$ white fluorescent lamps (Philips $40 \mathrm{~W}$ ) that provided an illumination of 2500 lux. In all cultivated flasks, conductivity, salinity, $\mathrm{pH}$, and temperature were daily quantified with Hanna (HI 09812-5) conductivity meter. The purity of cultures was periodically checked by microscopic observation following taxonomy guidelines. All solutions and glassware were autoclaved at $121^{\circ} \mathrm{C}$ for $15 \mathrm{~min}$ prior to utilization.

2.5. Cultivation of S. maxima at Large Scale for Production of $L$-Asparaginase. The inoculum from $5 \mathrm{~g} / \mathrm{L} \mathrm{NaNO}_{3}$ Spirulina maxima culture was cultured in $320 \mathrm{~L}$ glasses aquarium containing $300 \mathrm{~L}$ Zarrouk medium. The aquarium was incubated at the same conditions as described previously.

2.6. Growth Measurements. The growth rate of S. maxima was monitored every three days through the entire cultivation period by determining the dry weight (dw) and optical density (OD) at $560 \mathrm{~nm}$ by UV-vis spectrophotometer [18]. A good linear relationship between the biomasses DW concentration and the OD $560 \mathrm{~nm}$ was recorded. All analytical determinations were performed in triplicate and the mean values were recorded.

2.7. Harvesting. The algal cells were harvested at the stationary phase, by centrifugation at $10,000 \times \mathrm{g}\left(4^{\circ} \mathrm{C}\right)$ for $15 \mathrm{~min}$, and the cell masses were stored at $-20^{\circ} \mathrm{C}$ until analysis.

2.8. Rapid Screening of L-Asparaginase Production by Phenol Red Assay. Rapid screening of L-asparaginase produced from SM cultures was assessed based on Gulati et al. [19] method with the incorporation of $\mathrm{pH}$ indicator phenol red (prepared in ethanol) in MS L-asparagine. Phenol red at acidic $\mathrm{pH}$ is yellow and at alkaline $\mathrm{pH}$ turns pink; thus a pink color is formed by algal cultures producing L-asparaginase. Screening of potential L-asparaginase producing algae was carried out with the use of asparagine; $\mathrm{pH}$ was adjusted to 6.8 and supplemented with phenol red as a $\mathrm{pH}$ indicator $(0.009 \%$ final concentration). Tubes were examined for change in color of cultures from yellowish to pink due to change in $\mathrm{pH}$ indicating the positive asparaginase activity and used for further study.

2.9. Extraction of Crude L-Asparaginase Enzyme. Extraction of crude enzyme was done by adding $10 \mathrm{~mL}$ of sodium phosphate buffer ( $\mathrm{pH} 7)$ to the MS cultures, kept in rotator shaker for $45 \mathrm{~min}$. One $\mathrm{mL}$ of the extract was transferred to the Eppendorf tube and centrifuged at 10,000 $\times \mathrm{g}$ for 10 minutes. The obtained supernatant was used as crude extract for Lasparaginase assay.

2.10. L-Asparaginase Enzyme Extraction and Assay. L-asparaginase activity was determined by measuring the amount of ammonia released by nesslerization according to Wriston Jr. and Yellin [20] method. In brief, $0.2 \mathrm{~mL}$ of cell-free supernatant was mixed with $0.8 \mathrm{~mL}$ of $0.1 \mathrm{M}$ sodium borate buffer $(\mathrm{pH} 8.5$ ) and $1 \mathrm{~mL}$ of $0.04 \mathrm{M} \mathrm{L}$-asparagine and the reaction mixture was incubated for $10 \mathrm{~min}$. Then, $0.5 \mathrm{~mL}$ of $15 \%$ TCA was added to stop the reaction and centrifuged at 
TABLE 1: Effect of nitrogen concentration on growth of Spirulina maxima.

\begin{tabular}{lcccccccc}
\hline \multirow{2}{*}{ Nitrogen concentrations as $\mathrm{NaNO}_{3}$} & & \multicolumn{4}{c}{ Biomass (dry weight g/L) } & \multicolumn{2}{c}{ LSD $^{\mathrm{a}}$} \\
& Zero time & 3 & 6 & 9 & 12 & 15 & 18 \\
\hline $1.25 \mathrm{~g} / \mathrm{L}$ & 0.456 & 0.641 & 0.918 & 1.251 & 1.421 & 1.694 & 1.948 & 0.11 \\
$2.5 \mathrm{~g} / \mathrm{L}$ control & 0.462 & 0.932 & 1.234 & 1.657 & 1.869 & 2.245 & 2.456 & 0.16 \\
$5.0 \mathrm{~g} / \mathrm{L}$ & 0.455 & 1.421 & 1.891 & 2.361 & 2.457 & 2.961 & 3.456 & 0.21 \\
$\mathrm{LSD}^{\mathrm{b}}$ & 0.13 & 0.14 & 0.12 & 0.15 & 0.23 & 0.34 & 0.36 \\
\hline
\end{tabular}

Mean values of three replicates, LSD.

a: Least Significant Difference between any two means of time. b: Least Significant Difference between any two means of concentration.

$10000 \times \mathrm{g}$ for 10 minutes. $0.2 \mathrm{~mL}$ of the supernatant was taken in a test tube and $3.6 \mathrm{~mL}$ distilled water was added followed by additional $0.2 \mathrm{~mL}$ Nessler's reagent. The absorbance was measured spectrophotometrically at $480 \mathrm{~nm}$. The enzyme activity was expressed in IU. One IU of L-asparaginase is the amount of enzyme which liberates $1 \mu$ mole of ammonia per $\mathrm{mL}$ per $\min (\mu \mathrm{mole} / \mathrm{mL} / \mathrm{min})$ at $37^{\circ} \mathrm{C}$.

2.11. Purification of L-Asparaginase. The purification was carried out using crude enzyme extract. The enzyme was purified by the following steps: ammonium sulfate precipitation and Sephadex G-200 gel filtration, according to the modified method of Distasio et al. [21, 22]. After each step, the L-asparaginase activity and total protein content were determined.

2.12. Ammonium Sulfate Fractionation. The powder of ammonium sulfate was added gradually to the crude extract $(20-80 \%)$ reaching $80 \%$ saturation solution. The mixture was left for $12 \mathrm{~h}$ at $4^{\circ} \mathrm{C}$, followed by centrifugation at $8,000 \times \mathrm{g}$ for $20 \mathrm{~min}$ at $4^{\circ} \mathrm{C}$. The fractions precipitate was dissolved in a $0.01 \mathrm{M}$ phosphate buffer $\mathrm{pH} 8.5$ and dialyzed overnight against the same buffer at $4^{\circ} \mathrm{C}$.

2.13. Sephadex G-200 Gel Filtration. The dialyzed ammonium sulfate fraction was applied to a Sephadex G-200 column that was preequilibrated with a $0.01 \mathrm{M}$ phosphate buffer $\mathrm{pH}$ 8.5. Then, the protein fraction was eluted with the $0.01 \mathrm{M}$ phosphate buffer at a flow rate of $5 \mathrm{~mL} / 25 \mathrm{~min}$. It was assayed for protein quantity at $280 \mathrm{~nm}$ as well as for enzyme activity. The active fractions were pooled, dialyzed against the $0.01 \mathrm{M}$ phosphate buffer $\mathrm{pH} 8.5$, and concentrated.

2.14. Determination of Soluble Protein Content. The total protein content in soluble protein content and protein fractions was determined spectrophotometrically at $595 \mathrm{~nm}$, using Coomassie Blue ( $G$ 250) as mentioned by Bradford [23]. Bovine serum albumin (BSA) was used as a protein standard to preparation of calibration curve.

2.15. Kinetic Properties of L-Asparaginase Isolation from $S$. maxima. To determine the optimum $\mathrm{pH}$ and temperature of the AsnA enzyme, the activity of the purified S. maxima Lasparaginase was assessed by incubating the assay mixture under assay conditions as a function of varying ranging of $\mathrm{pH}\left(\mathrm{pH} 4.0,7.0,8.0\right.$, and 9.5) and temperature $\left(20-50^{\circ} \mathrm{C}\right)$.
2.16. Optimum of $p H$. The optimum $\mathrm{pH}$ of the enzyme was determined as reported by Singh et al. [24] using the following buffers: at $0.05 \mathrm{M}$ concentration: sodium acetate buffer ( $\mathrm{pH}$ 5-6), potassium phosphate buffer ( $\mathrm{pH}$ 6.5-7.5), and Tris- $\mathrm{HCl}$ buffer ( $\mathrm{pH} 8.0-9.5$ ). Blank assays were carried out without adding enzymes. The $\mathrm{pH}$ degree studies were carried out by preincubating the enzyme (AsnA) at different $\mathrm{pH}$ for $15 \mathrm{~min}$ and then the residual activity was measured.

2.17. Optimal Temperature. The optimal temperature of purified L-asparaginase enzyme activity was determined by preincubating the enzyme at desired temperature $\left(20-50^{\circ} \mathrm{C}\right)$ for $15 \mathrm{~min}$ and the amount of ammonia liberated was determined. At each temperature, blank assay was done without adding the enzyme.

2.18. Statistical Analysis. All measurements were carried out in triplicate. Statistical analyses were performed using oneway analysis of variance (ANOVA), and the significance of the difference between means was determined by Duncan's multiple range tests. Differences at $P<0.05$ were considered statistically significant. The results were presented as mean values ( $\pm \mathrm{SD}$, standard deviations).

\section{Results and Dissection}

3.1. Effect of Nitrogen Concentration on Growth of Spirulina maxima. Nitrogen is the major structural and functional element of algal cells and plays an important role in the nutrition in states. Nitrogen is required for all biosynthesis leading to reproduction, product formation, and cell maintenance. Production of the primary (proteins and carbohydrates) metabolite by microorganisms is highly influenced by their growth conditions. Table 1 and Figure 1 show the effect of $\mathrm{N}_{2}$ (as $\mathrm{NaNO}_{3}$ ) concentrations $(1.25,2.50$, and $5.0 \mathrm{~g} / \mathrm{L}$ ) in Zarrouk medium on algae growth for 18 days, as monitors by dry weight yields of biomasses (DWYg/L). The results showed that the DWY was significantly different $(P>0.5 \%)$ among all algae cultures at the incubation time interval. The biomass yield (g/L DW) was increased significantly among all cultures as the function of incubation times and nitrogen concentrations. The highest biomass yield recorded after 18 days of incubation was $3.456 \mathrm{mg} / \mathrm{L}, 2.456 \mathrm{mg} / \mathrm{L}$, and $1.948 \mathrm{mg} / \mathrm{L}$ in SM cultures grown in Zarrouk's medium containing $5.0 \mathrm{~g} / \mathrm{L}, 2.5 \mathrm{~g} / \mathrm{L}$, and $1.25 \mathrm{~g} / \mathrm{L} \mathrm{N}_{2}$, respectively. Thus, high biomass yield was noticed in S. maxima cultured in 
TABLE 2: Characterization of Spirulina maxima protein grown at nitrogen concentrations.

\begin{tabular}{lccc}
\hline Nitrogen concentrations as $\mathrm{NaNO}_{3}$ & Total protein \% DW & Soluble protein \% WD & Soluble protein yield mg/L \\
\hline $1.25 \mathrm{~g} / \mathrm{L}$ & $33.42 \pm 1.12$ & $20.12 \pm 1.22$ & $390 \pm 5.44$ \\
$2.5 \mathrm{~g} / \mathrm{L}$ control & $42.34 \pm 1.16$ & $33.23 \pm 1.65$ & $814 \pm 16.45$ \\
$5.0 \mathrm{~g} / \mathrm{L}$ & $56.36 \pm 2.32$ & $40.52 \pm 2.11$ & $1397.9 \pm 51.33$ \\
\hline
\end{tabular}

Mean values of three replicates, $\pm S D$.

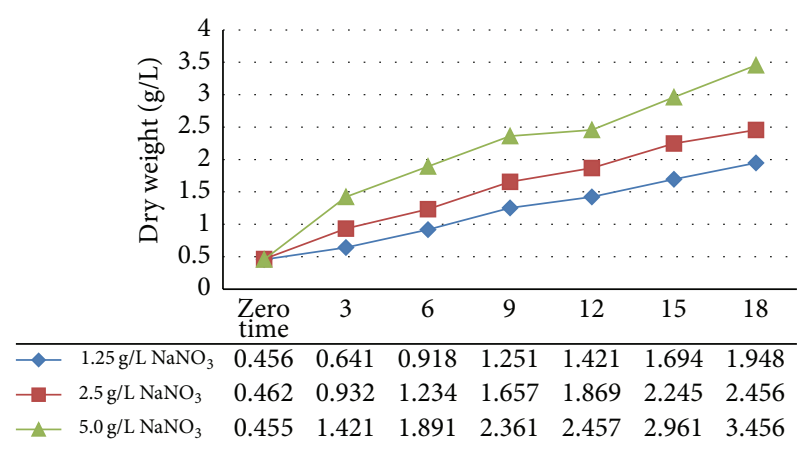

FIGURE 1: Effect of nitrogen concentration on growth of Spirulina maxima.

either high $(5.0 \mathrm{~g} / \mathrm{L})$ or optimal $(5.0 \mathrm{~g} / \mathrm{L}) \mathrm{N}_{2}$ concentrations compared with that noted in low $\mathrm{N}_{2}(1.25 \mathrm{~g} / \mathrm{L})$ culture. It is known well that nitrogen is an essential element of S. maxima growth and it grows well with high biomass yield [25]. Earlier studies also similarly showed that the yield of A. platensis biomass grown in rich or optimal $\mathrm{N}_{2}$ was higher than that in low $\mathrm{N}_{2}$ cultures [26]. However, it is important to note that certain algae species have the ability to adapt to the nutrient limitation (such as nitrogen, iron, and phosphorous) and stress environmental conditions (such as high light intensity and high salinity) by changes in its metabolic pathway [26, 27]. Similar results were reported in the literature $[25,28]$ that some algae species had great abilities to induce biomolecules including lipid, protein, and carbohydrates biosynthesis when grown in medium containing high $\mathrm{N}_{2}$ concentration [26]. In this context, our previous study showed that the created microalgae species grown under salt stress coupled with high $\mathrm{N}_{2}$ levels had high protein content. In general, environmental factors, nutrient status, and salinity lead to changes in cellular metabolic pathway and cellular composition [26]. These changes may be achieved at the expense of other main components such as lipids and carbohydrates.

3.2. Effect of Nitrogen Concentration on Protein Constituents of Spirulina maxima. Data in Table 2 shows the effect of nitrogen concentration on protein parameters including total protein (\% of dry weight (DW), TP), soluble protein $(\mathrm{mg} / \mathrm{g}$, $\mathrm{SPr}$ ), and soluble protein yield (mg/L, SPY) concentrations of Spirulina maxima (SM) growth in Zarrouk medium. These results indicate that the increase of nitrogen concentration in the Zarrouk nutrient media led to high changes in TP, SPr, and SPY contents in SP cells. At high $\mathrm{N}_{2} 5.0 \mathrm{~g} / \mathrm{L}$, the values of these constituents were $56.36 \%$ of DW, $40.52 \mathrm{mg} / \mathrm{g}$ of DW, and $1397.9 \mathrm{mg} / \mathrm{L}$, respectively. At limited $\mathrm{N}_{2} 1.225 \mathrm{~g} / \mathrm{L}$, these values were $33.42 \%$ of DW, $20.12 \mathrm{mg} / \mathrm{g}$ of DW, and $390 \mathrm{mg} / \mathrm{L}$, respectively. Thus, the protein constituents were increased in algal cells grown at high $\mathrm{N}_{2}$ by $2.51 \%, 4.11 \%$, and $9.01 \%$, respectively, as great as that in SP grown at low $\mathrm{N}_{2}$ concentration. Thus, the increase of $\mathrm{N}_{2}$ concentration in nutrient medium caused a significant increase of protein constituents in SM cultures. It could be noted that the total protein content increased with the increasing of $\mathrm{N}_{2}$ concentration in Zarrouk media. By this way, increasing the concentration of $\mathrm{N}_{2}$ in the nutrient medium over that optimal level can be manipulated with respect to its total proteins and soluble protein content. One would say that increase in $\mathrm{N}_{2}$ levels in growth medium may lead to increase in the protein synthesis required for increasing the metabolic pathway intracellular nitrogenous compounds in order to balance the high $\mathrm{N}_{2}$ concentration. However, it is well known that the nitrogen concentration in a medium has a great influence on protein content and its constituents in several species of Spirulina species. Piorreck et al. [27] reported that Spirulina, Chlorella, and many algae species grown in high nitrogen level showed high protein contents. Zeng and Vonshak [29] found that Spirulina cells grown under stress conditions, including salinity-stress, have a lower protein synthesis capacity. The finding results are in harmony with that of our findings [26] in Spirulina grown in medium containing high nitrogen with a high biomass production and total protein content as factors for macro- and microelements such as nitrogen source and concentrations. On the other hand, Becker [30] and Abd El-Baky and El-Baroty [26] reported that Spirulina spp. grown in a nitrogen-rich medium had a high ability to accumulate a considerable quantity of proteins $(>60 \%)$ and up to $20 \%$ of this protein fraction was identified as a phycocyanin blue pigment.

\subsection{Repaid Screening of L-Asparaginase Production by Tube} Assay. L-asparaginase (L-AsnA) activity of microalgae was rapid assay based on Gulati et al. [19] method. L-asparaginase production in Spirulina maxima grown in Zarrouk medium that contained various nitrogen concentration was colorimetrically assessed based on $\mathrm{pH}$ indicator phenol red (PR). Algal L-asparagine was incorporated into $0.009 \%$ methanolic phenol red-pH indicator; phenol red at acidic $\mathrm{pH}$ is yellow and in alkaline $\mathrm{pH}$ turns into pink colors. Thus, appearing of pink color indicates the hydrolysis of L-asparagine into aspartic acid and ammonia was released by L-asparaginase (L-AsnA) presence in Spirulina maxima (SM). Here, again, initial $\mathrm{pH}$ was changed from acidic (yellow) to basic (pink) due to the release of ammonia and this could be considered as positive result. After $5 \mathrm{~min}$ incubation period, aliquot 
TABLE 3: Effect of nitrogen concentrations on L-asparaginase production by Spirulina maxima.

\begin{tabular}{lcccc}
\hline \multirow{2}{*}{ Nitrogen concentrations as $\mathrm{NaNO}_{3}$} & Enzyme activity & \multicolumn{2}{c}{ Protein } & \multicolumn{2}{c}{ Specific activity } & \multicolumn{2}{c}{ Yield of enzyme } \\
& $\mathrm{IU}$ & $\mathrm{mg} / \mathrm{g}$ & $\mathrm{IU} / \mathrm{mg}$ & $\mathrm{IU} / \mathrm{L}$ \\
\hline $1.25 \mathrm{~g} / \mathrm{L}$ & $356 \pm 6.2$ & $212 \pm 3.5$ & $1.67 \pm 0.21$ & $32.39 \pm 2.6$ \\
$2.5 \mathrm{~g} / \mathrm{L}$ control & $594 \pm 6.5$ & $332 \pm 5.2$ & $1.79 \pm 0.11$ & $43.86 \pm 2.5$ \\
$5.0 \mathrm{~g} / \mathrm{L}$ & $898 \pm 11.6$ & $405 \pm 6.5$ & $2.21 \pm 0.22$ & $51.28 \pm 3.4$ \\
\hline
\end{tabular}

Mean values of three replicates, \pm SD.

TABLE 4: Purification of L-asparaginase from Spirulina maxima.

\begin{tabular}{lccccc}
\hline Sample & Enzyme activity IU & Protein mg & Specific activity IU/g & Fold purification & Enzyme yield\% \\
\hline Crude & 561 & 321.2 & 1.75 & 0.0 & 100 \\
Ammonium sulfate 80\% & 512 & 55.4 & 9.24 & 5.28 & 91.26 \\
Gel filtration & 485 & 25.4 & 19.1 & 10.91 & 86.45 \\
\hline
\end{tabular}

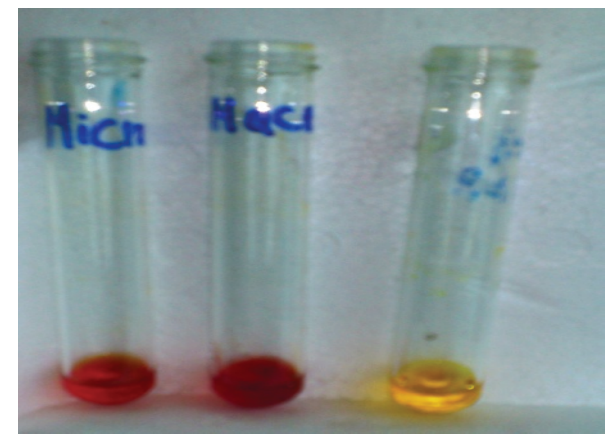

(a)

(b)

(c)

FIGURE 2: Detection of L-asparaginase (L-AsnA) activity of macroalgae and microalgae assayed by Gulati et al. [19] method using phenol red indicator: (a) L-AsnA production from microalgae, (b) LASase production from macroalgae, and (c) control without L-AsnA extract.

Spirulina extract with PR was changed to pink coloration and it indicates the presence of algal L-asparaginase with high activity (Figure 2). However, the depth of color intensity was increased with increasing L-AsnA activity and the deep pink colors were considered as L-AsnA producing species. Any algae cultures exhibiting L-AsnA activity were chosen for further study.

3.4. Effect of Nitrogen Concentrations on Enzyme Activity of L-Asparaginase Produced by Spirulina maxima. The enzyme activity of asparaginase produced by $S$. maxima grown in various nitrogen cultures was determined by evaluating enzyme activity IU, total protein, specific activity, and yield of enzyme in an aliquot of the SM enzyme extract (Table 3). In rich $\mathrm{N}_{2}$ algae cultures, these values were $898 \mathrm{IU}, 405 \mathrm{mg} / \mathrm{g}$, $2.21 \mathrm{IU} / \mathrm{mg}$ protein, and $51.28 \mathrm{IU} / \mathrm{L}$, respectively. At low $\mathrm{N}_{2}$ and optimal $\mathrm{N}_{2}$ (in parenthesis), these values were found to be $356 \mathrm{IU}$ (594 IU/L), $212 \mathrm{mg} / \mathrm{g}(332 \mathrm{mg} / \mathrm{g}), 1.667 \mathrm{IU} / \mathrm{mg}$ protein $(1.79 \mathrm{IU} / \mathrm{mg}$ protein), and $32.39 \mathrm{IU} / \mathrm{L}(43.86 \mathrm{IU} / \mathrm{L})$, respectively. This result revealed that the highest enzyme activities were recorded in SM cultures grown in high $\mathrm{N}_{2}$ medium when compared with that in optimal and low $\mathrm{N}_{2}$ cultures. Thus, algae grown in rich $\mathrm{N}_{2}$ medium were considered as high substrates and high enzyme activity correlated with good algae biomass yield. This result also showed significant differences among all various nitrogen cultures on the production of asparaginase by $S$. maxima.

3.5. Purification and Characterization of L-Asparaginase. Among all three SP cultures examined for synthesis of Lasparaginase, SP culture grown in high $\mathrm{N}$ concentration medium characterized by high yields enzyme $51.28 \mathrm{U} / \mathrm{L}$ and high enzyme activity (898 IU) and protein enzyme (405 mg/ g) content was selected for further studies. The characterization parameters of its high synthesis of L-asparaginase in S. maxima cultures purification of crude enzyme was performed by $80 \%$ ammonium sulfate precipitation and gel filtration GF purification steps is summarized in Table 4 . Both the purification methods showed a significant effect to improve the enzyme characterization as high as that in crude enzyme extracts. The values of enzyme activity IU, total protein $\mathrm{mg} / \mathrm{g}$ in aliquot of enzyme extract, specific activity IU/mg protein, and yield of enzyme IU/L (Table 2) of $80 \%$ AS and GF (in parenthesis) purification methods were $515 \mathrm{IU}$ (485 IU), $485 \mathrm{mg} / \mathrm{g}, 55.4 \mathrm{IU} / \mathrm{mg}$ protein $(25.4 \mathrm{IU} / \mathrm{mg}$ protein), and 9.24 IU/L (19.1 IU/L), respectively. These values revealed that the AsnA enzyme of $S$. maxima purified by GF had a high specific activity of $19.1 \mathrm{IU} / \mathrm{g}$ and was found to be of approximately 2 -fold purity compared to $80 \%$ AS purification method. However, $80 \%$ AS and GF purified process showed a high enzyme purification 5.28- and 10.91fold greater than that in crude enzyme extract (Table 3 ). However, the percentages of the enzyme yield (\%) of purified L-asparaginase crude extract by $80 \%$ AS precipitation and GF were $91.26 \%$ and $86.45 \%$, respectively, of crude extract (\%). Thus, the enzyme yield was retained after purification steps with $91.26 \%$ and 86.45 of crude enzyme. Thus, in this study, L-asparaginase was precipitated at $80 \%$ ammonium sulfate which leads to high fold in yield and purification of enzyme but it was less than that by GF. The total soluble protein content was decreased from $321.2 \mathrm{mg} / \mathrm{mL}$ of its original concentration of 55.4 and $25.4 \mathrm{mg} / \mathrm{mL}$ in purified AsnA 


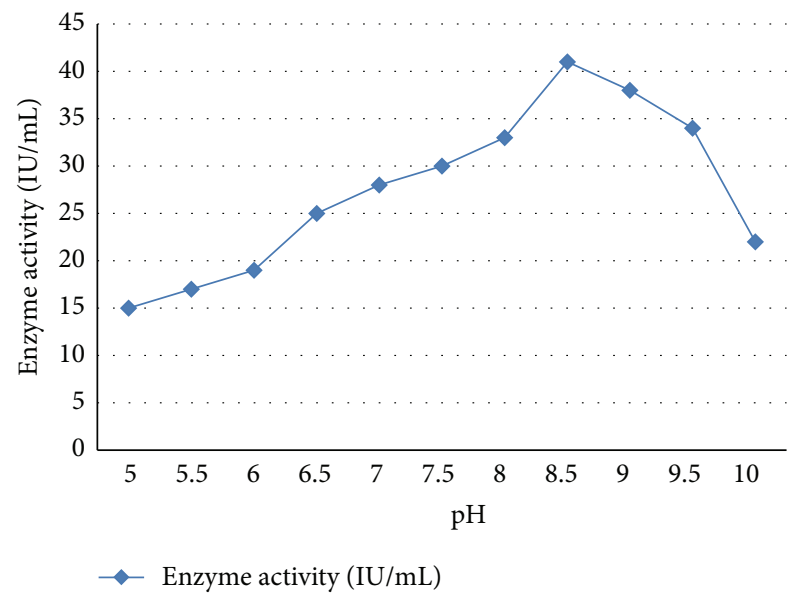

FIgURE 3: Effect of $\mathrm{pH}$ on Spirulina maxima L-asparaginase activity. Enzyme samples (containing $1 \mathrm{mg} / \mathrm{mL}$ of protein) were incubated at $\mathrm{pH}$ ranges from 5 to 10 .

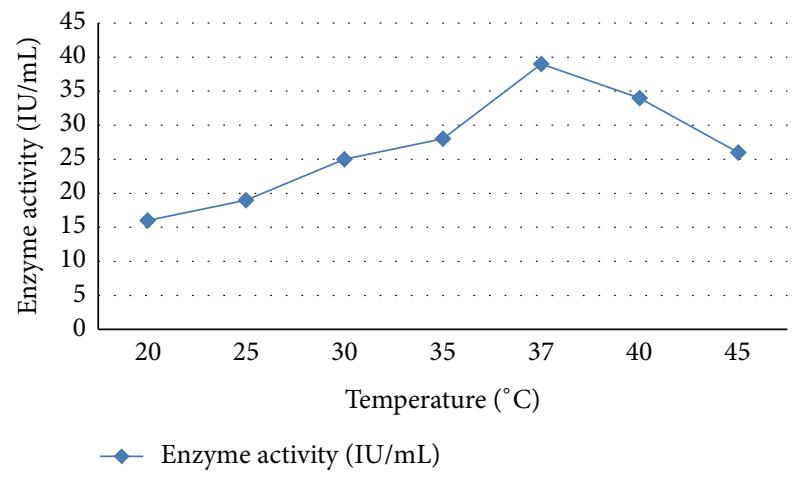

FIGURE 4: The effect of temperature on the stability of L-asparaginase activity. Enzyme samples (containing $1 \mathrm{mg} / \mathrm{mL}$ of protein) were incubated at temperature ranges from 20 to $45^{\circ} \mathrm{C}$.

enzyme by using AS and GF purification steps, respectively (Table 3). El-Bessoumy et al. [5] found that the purified LAsnA from Pseudomonas aeruginosa reached 106-fold by 3 steps of purification (AS precipitation and GF on Sephadex G-100 column followed by CM-Sephadex C50 column).

3.6. Physiochemical Properties of L-Asparaginase from SM Culture. In the final purification steps, GF enzyme showed a high specific activity of $19.1 \mathrm{IU} / \mathrm{mg}$, with approximately 12 fold purity and 68.45 enzyme yields. Therefore, the optimal $\mathrm{pH}$ and the temperature degrees of S. maxima AsnA enzyme purified by GF step are (Figures 3 and 4 ) determined. The results showed that the enzyme exhibited maximum activity $42 \mathrm{IU} / \mathrm{mL}$ at $\mathrm{pH} 8.3$ and 8.5 and optimum temperature was $36.5^{\circ} \mathrm{C}-37^{\circ} \mathrm{C}$. Similar results were found in many microbial species such as Mycobacterium spp., S. ginsengisoli, and Pseudomonas spp. and optimum temperature was $37^{\circ} \mathrm{C}$ and optimum $\mathrm{pH}$ was in the range of $8-8.5$, which is close to optimum $\mathrm{pH}$ recorded for L-asparaginase obtained in this study $[9,31]$.

In general, the optimum activity of purified AsnA enzyme was recorded at the $\mathrm{pH} 8.5$ and $37 \pm 0.42^{\circ} \mathrm{C}$ the optimum temperature in many of microbial species. In this regard, ElBessoumy et al. [5] reported that maximum activity of Lasparaginase of $P$. aeruginosa was obtained at $\mathrm{pH} 8.5$ and optimal temperature $37 \pm 0.42^{\circ} \mathrm{C}$. The enzyme from Enterobacter cloacae had a $\mathrm{pH}$ and temperature optimum of 8.5 and $37 \pm 42^{\circ} \mathrm{C}$, respectively [9]. In contrast, the asparaginase from P. geniculata, P. stutzeri, and Aspergillus niger has a $\mathrm{pH}$ optimum of 9.0 [8]. The physicochemical properties of Lasparaginase from S. maxima are within the range reported for the L-asparaginases of many microorganisms, in the alkaline region ( $\mathrm{pH}$ 8-9). Makky et al. [31] reported that the specific activity of the pure enzyme isolated by Streptobacillus sp. was recorded to be $21.77 \mathrm{U} / \mathrm{mg}$ with 39.58 -fold purification and $39 \%$ of yield. Finally, the maximum enzyme activity of S. maxima was found to be at/or near physiological $\mathrm{pH}$ and temperature, making it extremely valuable in the chemotherapeutic treatment of some diseases such as cancer.

\section{Conclusion}

Spirulina maxima (SM) cultures grown in Zarrouk medium containing high $\mathrm{N}_{2}(5 \mathrm{~g} / \mathrm{L})$ as $\mathrm{NaNO}_{3}$ level for 18 days showed high dry biomass yields $(1.948 \mathrm{~g} / \mathrm{L}$ ) and L-asparaginase (LAsnA) enzyme production, total protein $405 \mathrm{mg} / \mathrm{g}$, specific activity $2.21 \mathrm{IU} / \mathrm{mg}$ protein, and yield of enzyme $51.28 \mathrm{IU} / \mathrm{L}$ compared with those obtained in either optimal $\mathrm{N}_{2}(2.5 \mathrm{~g} / \mathrm{L})$ or low $\mathrm{N}_{2}(1.25 \mathrm{~g} / \mathrm{L})$ concentration culture. The partial purification of crude MS L-asparaginase enzyme achieved by $80 \%$ ammonium sulfate prepetition and gel filtration had a high specific activity greater by 5.28 and 10.91 than that in crude enzyme extract. The optimum activity of purified enzyme was recorded at 8.5 and $37 \pm 0.2$.

\section{Competing Interests}

The authors declare that there is no conflict of interests regarding the publication of this paper.

\section{Acknowledgments}

The authors gratefully acknowledge financial support Grant no. 10090001 from National Research Centre, Cairo, Egypt.

\section{References}

[1] G. M. Cooper, The Cell: A Molecular approach, ASM Press, Washington, DC, USA, 2nd edition, 2000.

[2] N. Verma, K. Kumar, G. Kaur, and S. Anand, "L-asparaginase: a promising chemotherapeutic agent," Critical Reviews in Biotechnology, vol. 27, no. 1, pp. 45-62, 2007.

[3] W. K. Chan, P. L. Lorenzi, A. Anishkin et al., "The glutaminase activity of L- Asparaginase is not required for anticancer activity against ASNS-negative cells," Blood, vol. 123, no. 23, pp. 35963606, 2014.

[4] N. E.-A. El-Naggar, H. Moawad, N. M. El-Shweihy, and S. M. El-Ewasy, "Optimization of culture conditions for production of the anti-leukemic glutaminase free L-asparaginase by newly 
isolated Streptomyces olivaceus NEAE-119 using response surface methodology," BioMed Research International, vol. 2015, Article ID 627031, 17 pages, 2015.

[5] A. A. El-Bessoumy, M. Sarhan, and J. Mansour, "Production, isolation, and purification of L-asparaginase from Pseudomonas Aeruginosa 50071 using solid-state fermentation," Journal of Biochemistry and Molecular Biology, vol. 37, no. 4, pp. 387-393, 2004.

[6] G. A. Kotzia and N. E. Labrou, "L-Asparaginase from Erwinia chrysanthemi 3937: cloning, expression and characterization," Journal of Biotechnology, vol. 127, no. 4, pp. 657-669, 2007.

[7] R. V. Mahajan, S. Saran, K. Kameswaran, V. Kumar, and R. K. Saxena, "Efficient production of l-asparaginase from Bacillus licheniformis with low-glutaminase activity: optimization, scale up and acrylamide degradation studies," Bioresource Technology, vol. 125, pp. 11-16, 2012.

[8] A. Mishra, "Production of L-asparaginase, an anticancer agent, from Aspergillus niger using agricultural waste in solid state fermentation," Applied Biochemistry and Biotechnology, vol. 135, no. 1, pp. 33-42, 2006.

[9] M. S. Nawaz, D. Zhang, A. A. Khan, and C. E. Cerniglia, "Isolation and characterization of Enterobacter cloacae capable of metabolizing asparagine," Applied Microbiology and Biotechnology, vol. 50, no. 5, pp. 568-572, 1998.

[10] S. Ghosh, S. Murthy, S. Govindasamy, and M. Chandrasekaran, "Optimization of L-asparaginase production by Serratia marcescens (NCIM 2919) under solid state fermentation using coconut oil cake," Sustainable Chemical Processes, vol. 1, no. 1, article 9, 2013.

[11] S. Kalra, A. Midha, and A. Kaur, "Production, purification and characterization of L-asparaginase from Pseudomonas aeruginosa 2488 using fermentation," International Journal of Advanced Research, vol. 4, no. 1, pp. 541-549, 2016.

[12] M. L. Bongers, J. G. F. Hogervorst, L. J. Schouten, R. A. Goldbohm, H. C. Schouten, and P. A. van den Brandt, "Dietary acrylamide intake and the risk of lymphatic malignancies: The Netherlands Cohort Study on Diet and Cancer," PLoS ONE, vol. 7, no. 6, article e38016, 2012.

[13] E. Tareke, P. Rydberg, P. Karlsson, S. Eriksson, and M. Törnqvist, "Analysis of acrylamide, a carcinogen formed in heated foodstuffs," Journal of Agricultural and Food Chemistry, vol. 50, no. 17, pp. 4998-5006, 2002.

[14] N. S. M. Kumar, C. A. Shimray, D. Indrani, and H. K. Manonmani, "Reduction of Acrylamide formation in sweet bread with L-asparaginase treatment," Food and Bioprocess Technology, vol. 7, no. 3, pp. 741-748, 2014.

[15] Y. Onishi, A. A. Prihanto, S. Yano, K. Takagi, M. Umekawa, and M. Wakayama, "Effective treatment for suppression of acrylamide formation in fried potato chips using L-asparaginase from Bacillus subtilis," 3 Biotech, vol. 5, no. 5, pp. 783-789, 2015.

[16] A. A. Prihanto and M. Wakayama, "Combination of environmental stress and localization of L-asparaginase in Arthrospira platensis for production improvement," 3 Biotech, vol. 4, no. 6 , pp. 647-653, 2014.

[17] C. Zarrouk, Contribution a letuded unecyanobacterie: influence de divers facteurs physiques et chimiquessur la croissance et la photosynthese de Spirulina maxima (Setchell et Gardner) Geitler [Ph.D. thesis], University of Paris, Paris, France, 1966.

[18] A. Vonshak, Spirulina platensis (Arthrospira): Physiology, Cell Biology and Biotechnology, Taylor and Francis, London, UK, 1997.
[19] R. Gulati, R. K. Saxena, and R. Gupta, "A rapid plate assay for screening L-asparaginase producing micro-organisms," Letters in Applied Microbiology, vol. 24, no. 1, pp. 23-26, 1997.

[20] J. C. Wriston Jr. and T. O. Yellin, "L-asparaginase: a review," Advances in Enzymology and Related Areas of Molecular Biology, vol. 39, pp. 185-248, 1973.

[21] J. A. Distasio, R. A. Nredrerman, D. Kafkewitz, and D. Goodman, "Purification and characterization of L-asparaginase with antilymphoma activity from Vibroi succinogenes," The Journal of Biological Chemistry, vol. 251, pp. 6929-6933, 1976.

[22] J. A. Distasio, A. M. Salazar, M. Nadji, and D. L. Durden, "Glutaminase-free asparaginase from Vibrio succinogenes: an antilymphoma enzyme lacking hepatotoxicity," International Journal of Cancer, vol. 30, no. 3, pp. 343-347, 1982.

[23] M. M. Bradford, "A rapid and sensitive method for the quantitation of microgram quantities of protein utilizing the principle of protein-dye binding," Analytical Biochemistry, vol. 72, no. 1-2, pp. 248-254, 1976.

[24] Y. Singh, R. K. Gundampati, M. V. Jagannadham, and S. K. Srivastava, "Extracellular L-asparaginase from a proteasedeficient Bacillus aryabhattai ITBHU02: purification, biochemical characterization, and evaluation of antineoplastic activity in vitro," Applied Biochemistry and Biotechnology, vol. 171, no. 7, pp. 1759-1774, 2013.

[25] H. H. Abd El Baky, F. K. El-Baz, and G. S. El Baroty, "Enhancing antioxidant availability in wheat grains from plants grown under seawater stress in response to microalgae extract treatments," Journal of the Science of Food and Agriculture, vol. 90, no. 2, pp. 299-303, 2010.

[26] H. H. Abd El-Baky and G. S. El-Baroty, "The potential use of microalgal carotenoids as dietary supplements and natural preservative ingredients," Journal of Aquatic Food Product Technology, vol. 22, no. 4, pp. 392-406, 2013.

[27] M. Piorreck, K.-H. Baasch, and P. Pohl, "Biomass production, total protein, chlorophylls, lipids and fatty acids of freshwater green and blue-green algae under different nitrogen regimes," Phytochemistry, vol. 23, no. 2, pp. 207-216, 1984.

[28] H. H. Abd El-Baky, F. K. El Baz, and G. S. El-Baroty, "Production of phenolic compounds from Spirulina maxima microalgae and its protective effects in vitro toward hepatotoxicity model," African Journal of Pharmacy and Pharmacology, vol. 3, no. 4, pp. 133-139, 2009.

[29] M.-T. Zeng and A. Vonshak, "Adaptation of Spirulina platensis to salinity-stress," Comparative Biochemistry and Physiology Part A: Molecular \& Integrative Physiology, vol. 120, no. 1, pp. 113-118, 1998.

[30] E. W. Becker, Microalgae: Biotechnology and Microbiology, Cambridge University Press, Cambridge, UK, 1994.

[31] E. A. Makky, Y. C. Loh, and M. R. Karim, "Purification and partial characterization of a low molecular weight L-asparaginase produced from corn cob waste," Biocatalysis and Agricultural Biotechnology, vol. 3, no. 4, pp. 265-270, 2014. 


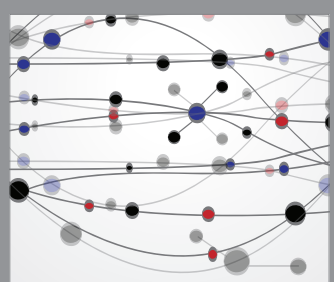

The Scientific World Journal
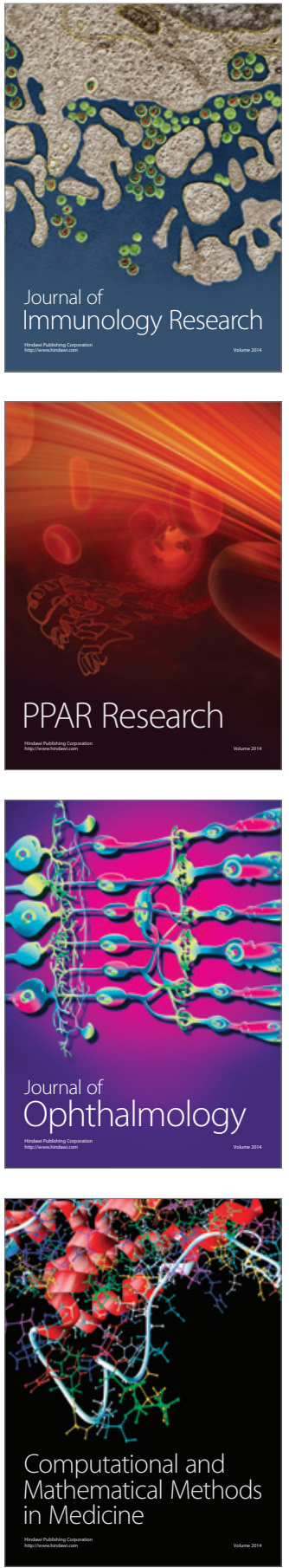

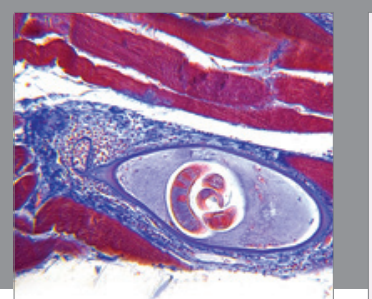

Gastroenterology Research and Practice

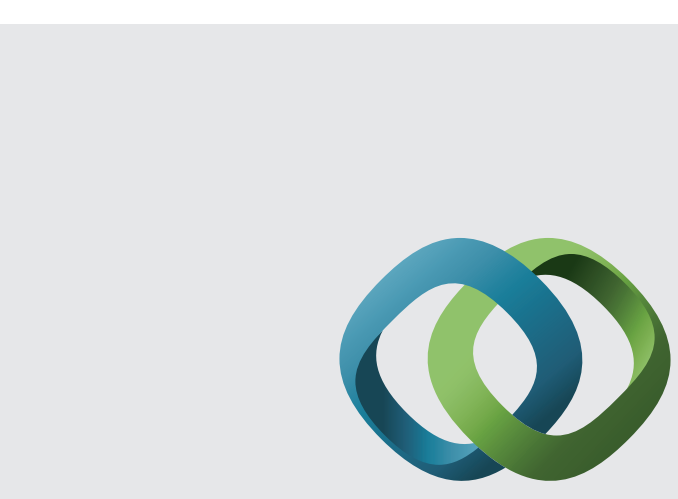

\section{Hindawi}

Submit your manuscripts at

http://www.hindawi.com
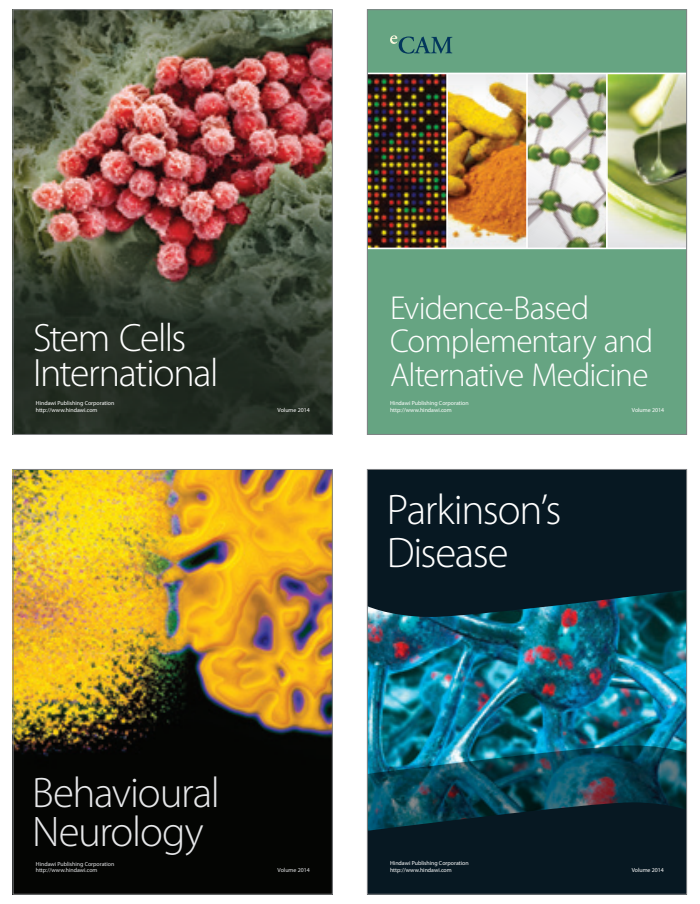
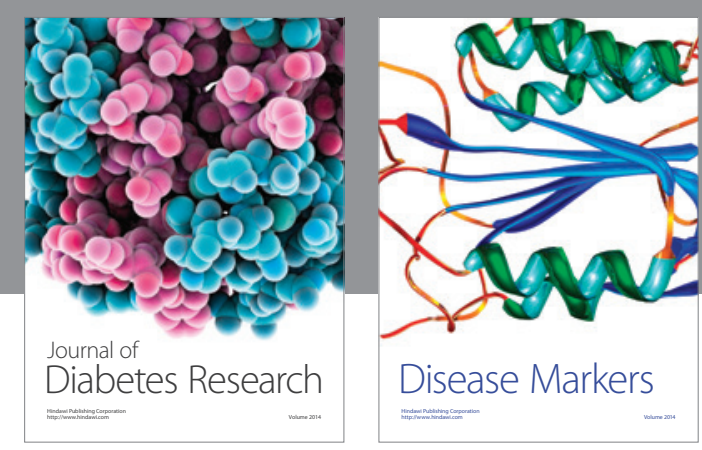

Disease Markers
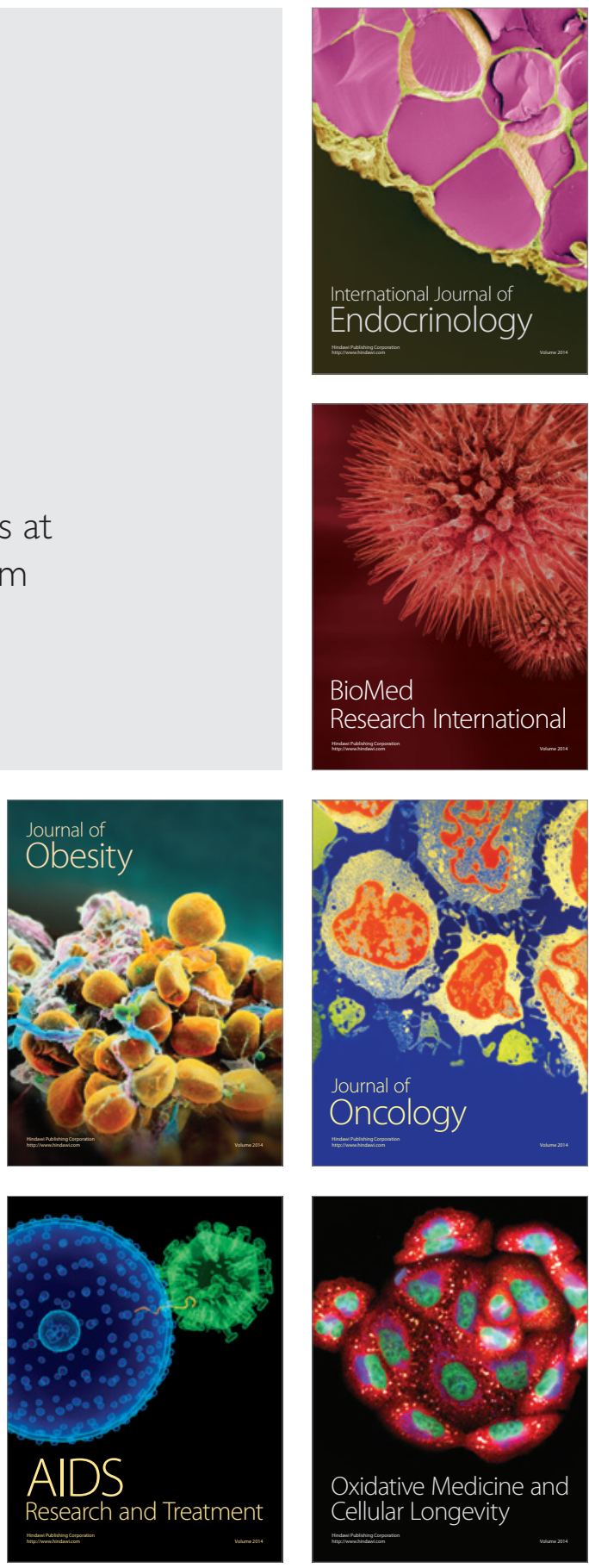